\begin{tabular}{|c|c|c|}
\hline 010 & $\begin{array}{c}\text { Türkiye Tarımsal Araştırmalar Dergisi } \\
\text { dergipark.org.tr/tutad }\end{array}$ & $\begin{array}{l}\text { Turk J Agric Res } \\
\text { 2021, 8(2): 213-219 } \\
\text { ๑ TÜTAD }\end{array}$ \\
\hline $\begin{array}{l}\text { SiïT } \\
\text { ÜNiVERSiTESi } \\
\text { Bilimin Nüuminda }\end{array}$ & Research Article & $\begin{array}{l}\text { ISSN: } 2148-2306 \\
\text { e-ISSN: } 2528-858 \mathrm{X} \\
\text { doi: 10.19159/tutad.890935 }\end{array}$ \\
\hline
\end{tabular}

\title{
Comparative Evaluation of Two Commercial Propolis Extracts as Plant Defense Activator and Antimicrobial Agent Against Pseudomonas syringae pv. tomato (Pst) strain DC3000
}

\author{
Melda ATEŞ ${ }^{1}$, Nazlı ÖZKURT ${ }^{1}$, Yasemin BEKTAŞ ${ }^{2 *}$ \\ ${ }^{I}$ Gaziosmanpaşa University, Faculty of Science and Letters, Department of Molecular Biology and Genetics, Tokat, TURKEY \\ ${ }^{2}$ Siirt University, Faculty of Agriculture, Department of Agricultural Biotechnology, Siirt, TURKEY
}

\begin{tabular}{l}
\hline Received: 04.03.2021 Accepted: 13.06 .2021 \\
\hline ORCID ID (By author order) \\
(1D) orcid.org/0000-0002-7486-1773 (D) orcid.org/0000-0003-4064-3740 (1D) orcid.org/0000-0002-6884-2234 \\
"Corresponding Author: yas.aktas@gmail.com
\end{tabular}

\begin{abstract}
Propolis is a natural bee product that protects the beehives from internal and external factors. It is a natural-complex compound with a wide potential use as an antimicrobial, anti-fungal, and anti-inflammatory effect. The role of propolis as a plant protection agent and an alternative to pesticides is an unexplored area. Here, two different commercially available propolis extracts were evaluated for antibacterial effects on Pseudomonas syringae pv. tomato (Pst) strain DC3000. Also, the activities of defense response genes WRKY70 and CaBP22 in Arabidopsis thaliana under propolis application were compared. According to the results, each propolis extract and dose had a different effect on gene expressions as well as antibacterial activity. One of the commercial brands had a significant effect at all doses while another brand's propolis extract had its activity at only $1 \%$ concentration. Propolis reduced bacterial growth up to $93 \%$ with a $2 \%$ concentration. For the first time, propolis is also evaluated for its capacity as a plant defense activator agent and it induced WRKY70 and CaBP22 gene expression. The differences in gene expression and bacterial growth inhibition levels suggest the importance of the origins of propolis, such as plant species and regions it collected. While preliminary in nature, these results suggest a significant potential of propolis in plant protection in commercial and organic agriculture.
\end{abstract}

Keywords: Antibacterial activity, Apis mellifera, plant defense response, plant protection, propolis, Pseudomonas syringae pv. tomato (Pst) strain DC3000

\section{Introduction}

Propolis, bee glue, is a resin-like substance that is collected by Apis mellifera bees from different plants and mixed with secreted beeswax. Bees use propolis as a building material and a defensive substance against pathogens in the beehives (Sforcin and Bankova, 2011; Pascoal et al., 2014). Since ancient times propolis has got attention and is widely used by humans for its medicinal properties in folk medicine. Greeks, Romans, and Egyptians used propolis as early as $3000 \mathrm{BCE}$ for disinfecting and healing of wounds (Burdock, 1998; Zabaiou et al., 2017). Propolis contains a complex mixture of compounds and its composition depends on the source plant species used by honeybees (Wagh, 2013; Huang et al., 2014; Pascoal et al., 2014). Hence, propolis is enriched in flavonoids, phenolic acids, and terpene derivatives and widely used for its antibacterial, antioxidant, and anti-inflammatory properties (Sforcin and Bankova, 2011; Zabaiou et al., 2017; Zampini et al., 2021). Even though standardization of propolis composition is a challenge, chemical analysis demonstrates its valuable structure to use in many fields (Salatino et al., 2005; Wagh, 2013). Numerous studies have reported many biological activities of propolis like antimicrobial (Regueira et al., 2017; Kolayli et al., 2020), antioxidant (Jug et al., 2014; Martinello and Mutinelli, 2021), anti-inflammatory (Lima Cavendish et al., 2015), anti-fungal (Gallez et al., 2015; Freires et al., 2016) and anti-cancer effects (Botteon et al., 2021). Its anticancer properties were investigated against several types of cancer, including renal cell carcinoma (Valente et al., 
2011), pancreatic (Awale et al., 2008), and colon cancers (Ishihara et al., 2009). Also, studies showed promising effects of propolis on diabetes, obesity, and human oral health (Rivera-Yañez et al., 2020; Da Silva Barboza et al., 2021). Propolis could also reduce severe symptoms of patients with the new coronavirus (SARS-Cov-2) (Scorza et al., 2020; Xu and Zhang, 2020; Ali and Kunugi, 2021). According to studies, it is not only used in human health but also used in animal health (Abd-ElRhman, 2009) and the food industry. It can be used as active packaging films and edible coatings (Aparicio-García et al., 2021; Yong and Liu, 2021), food additive, and functional food ingredient, because of its antimicrobial and antioxidant properties (Zampini et al., 2021). Several propolis studies on plant research showed that it can protect against Fusarium circinatum when applied as a seed coating agent (Silva-Castro et al., 2018). Also, its antibacterial activity was tested for many phytopathogenic bacteria and it is reported to have a wide spectrum of effects against them (Basim et al., 2006; Ordonez et al., 2011; Er, 2021), and in the control of major potato pests and diseases (Bohinc et al., 2019). Moreover, foliar application of Argentinian propolis on tomato fruits infected with Pseudomonas syringae reduced the severity of disease (Ordonez et al., 2011). Egyptian propolis reduced tomato bacterial wilt caused by Ralstonia solanacearum under greenhouse and field conditions (Abo-Elyousr et al., 2017).

As a natural compound with proven pharmacological properties, propolis has wide application potential in human, animal, and plant health. Numerous studies showed its effectiveness in many areas. Also, plant researches showed that propolis has an antibacterial effect against phytopathogens. Antimicrobial agents have been widely used for human, animal, and plant health. Recent studies showed that the application of antibacterial agents may also induce defense responses and protect the organism against pathogen through induction of immunity (Henry et al., 2011; Cai et al., 2014; Farace et al., 2015; Halder et al., 2019). Therefore, this study aimed, 1) to compare two commercially available propolis extracts for their antimicrobial activity against Pseudomonas syringae pv. tomato (Pst) strain DC3000, and 2) to investigate plant defense activation of propolis in Arabidopsis thaliana, to evaluate the potential activity of propolis on plant protection.

\section{Materials and Methods}

\subsection{Plant material and growth conditions}

Arabidopsis (Arabidopsis thaliana L. Heynh.) plants were grown in a peat-perlite mixture $(2: 1)$ under fluorescent lights ( $16 \mathrm{~h}$ of light $/ 8 \mathrm{~h}$ of dark) in a growth room at the Turkey-Tokat Gaziosmanpasa University, Department of Molecular Biology and Genetics. Surface sterilized wild type Columbia-0 (Col-0) seeds were sown in pots and left to grow for one week. For growth assay; $5 \mathrm{~mL}$ of the indicated concentration of propolis extracts $(0.1,1$, and $2 \%)$ were poured into drainage plate, and plants were irrigated with propolis extract, while control was irrigated with distilled water for three weeks. Four-week-old plants were harvested for growth assay. The experiments were repeated at least three times.

\subsection{Bacterial culture and in-vitro assay}

Pseudomonas syringae pv. tomato (Pst) strain DC3000 was grown on King's B (KB) medium overnight at $28^{\circ} \mathrm{C}$ in an incubator. For the in-vitro assay, autoclaved $\left(121{ }^{\circ} \mathrm{C}, 20 \mathrm{~min}\right) \mathrm{KB}$ medium consisting of $20 \mathrm{~g}$ of peptone, $1.5 \mathrm{~g}$ of potassium phosphate diabasic, $1.5 \mathrm{~g}$ of magnesium chloride hexahydrate, $20 \mathrm{ml}$ of $50 \%$ glycerol, $7.5 \mathrm{~g}$ of agar filled with $\mathrm{ddH}_{2} \mathrm{O}$, were used. Propolis extracts or water as control were added to autoclaved and warmed $\mathrm{KB}$ medium until $0.1,1$, and $2 \%$ propolis concentrations. Overnight-grown Pst DC3000 culture concentration adjusted to OD600: 0.02 and $100 \mathrm{uL}$ of Pst DC3000 were spread to prepared plates. Cultures were grown for 24 hours at $28{ }^{\circ} \mathrm{C}$ in an incubator. All bacteria were collected gently by adding $10 \mathrm{ml} \mathrm{MgCl} 2$ solution onto agar plates after 24 hours. The collected bacteria cultures were measured with a spectrophotometer at $600 \mathrm{~nm}$ optical density. The experiments were repeated at least three times.

\subsection{Propolis extracts}

Commercially available Balen ${ }^{\mathrm{R}}(\mathrm{BN})$ and Aksu Vital Shiffa Home ${ }^{R}(\mathrm{AH})$ brands of water-based liquid propolis extracts, with 14.4 and $90 \%$ indicated concentrations, respectively, were used. For gene expression and growth assays, propolis was diluted with sterile distilled water to final concentrations $(0.1,1$, and $2 \%)$. Plants were irrigated with each indicated concentration or distilled water as control. For the in-vitro assay, the $\mathrm{KB}$ agar medium was adjusted with a proper amount of propolis until reaching $0.1,1$, and $2 \%$ concentrations. 
2.4. Semi-Quantitative reverse transcriptionpolymerase chain reaction

Defense gene expression assays were done with 4 weeks old Arabidopsis plants. Indicated concentrations of propolis or control water were poured into the drainage plate to induce plants from the roots for 24 hours. The tissue samples were collected after 24 hours of application. RNA was isolated from seedlings using Ambion PureLink ${ }^{\circledR}$ RNA Mini Kit. cDNAs were prepared using RevertAid First Strand cDNA Synthesis Kit. One uM of cDNA was used for all PCRs. Thermo Scientific DreamTaq PCR Master Mix (2X) was used for RT-PCR. Actin 8 was amplified as a loading control and the expression of WRKY70 and CaBP 22 defense genes (Table 1) were analyzed with semiquantitative RT-PCR. PCR products were electrophoresed on $1.6 \%$ agarose gels containing $0.5 \mathrm{ug} \mathrm{ml}^{-1}$ ethidium bromide.

Table 1. Forward and reverse primer sequences of genes of interest

\begin{tabular}{ll}
\hline \multirow{2}{*}{ Actin8 } & F : 5'-ATGAAGATTAAGGTCGTGGCAC-3' \\
& R : 5'-GTTTTTATCCGAGTTTGAAGAGGC-3' \\
\hline \multirow{2}{*}{ CaBP22 } & F: 5'-CGGAACCATCAATTTCACTGAGT-3' \\
& R: 5'-CAAAGTGCCACCAGTTGTGTCAT-3' \\
\hline \multirow{2}{*}{ WRKY70 } & $\begin{array}{l}\text { F: 5'AACGACGGCAAGTTTGAAGATTC-3' } \\
\text { R: 5'TTCTGGCCACACCAATGACAAGT-3' }\end{array}$ \\
\hline
\end{tabular}

\subsection{Statistical analysis}

The student's t-test function of Microsoft excel ver. (2016) was used to determine if the propolis affected the growth of the plants and to determine if the effects of the propolis on bacterial growth were statistically significant.

\section{Results and Discussion}

Propolis is a resinous bee product used as a coating material to protect beehives from pathogens. It has been used as a folk medicine for its antiseptic, antimicrobial, and other properties for centuries (Burdock, 1998; Zabaiou et al., 2017). Many studies published about its chemical composition and biological activities (Wagh, 2013; Pascoal et al., 2014). In this study, two commercially available liquid propolis extract $\left(\right.$ Balen $^{\mathrm{R}}$ and Aksu Vital Shiffa Home $^{\mathrm{R}}$ ) were evaluated and compared for antibacterial activity, effect on plant growth, and plant defense gene-inducing capability.

\subsection{Two commercially available propolis} extracts showed different anti-microbial activities against Pseudomonas syringae pv. tomato (Pst) strain DC3000

Pseudomonas syringae pv. tomato (Pst) strain DC3000 is an important phytopathogen and causes dramatic yield losses every year on tomatoes (Xin and He, 2013). It does not only infect tomato plants but also infects other plant species including model plant $A$. thaliana. There is still no completely successful disease control management against Pst DC3000. As a course of its nature, propolis is a promising agent to protect plants against Pst DC3000. In this study, the antibacterial activity of water-based liquid propolis extracts $\left(\right.$ Balen $^{\mathrm{R}}$; BN and Aksu Vital Shiffa Home ${ }^{\mathrm{R}}$; AH) against Pst DC3000 were tested and their side-by-side activities were compared. According to the results, both propolis products have an antibacterial effect against Pst DC3000, however, their dose impacts were different (Figure 1). The $\mathrm{BN}$ showed significant antimicrobial activity on every concentration $(0.1,1$, and $2 \%)$ and bacterial growths were declined dramatically as the percentage of $\mathrm{BN}$ propolis increased. 0.1, 1 and 2\% concentrations inhibited bacterial growth by $4.5,66$, and $93 \%$, respectively compared to control. The antibacterial effect of $\mathrm{AH}$ was not as strong as $\mathrm{BN}$. The $\mathrm{AH}$ inhibited bacterial growth at only $1 \%$ concentration (Figure 1) and it reduced bacterial growth by only $4 \%$ compared to control. Even though $2 \%$ AH did not show a significant antibacterial activity, it reduced bacterial growth, however, its activity was significantly lower than BN. Antibacterial activity of $\mathrm{BN}$ and $\mathrm{AH}$ may be different because of the collected place and/or time of the propolis as well as plant origin and ingredients of the propolis. Even packaging of propolis may affect the antibacterial quality of the compounds. Basim et al. (2006) evaluated propolis that was collected from the South-East Mediterranean region of Turkey, against several phytopathogens including Pst. They used the paper disc diffusion method and detected the antibacterial activity of propolis extracts against several phytopathogens. They showed that propolis inhibits bacterial growth differently on different pathogens. These results demonstrated that the resistance of bacteria, as well as the content of propolis, is important to exhibit the antibacterial activity of propolis. Therefore, it is necessary to evaluate each propolis source separately and make comparisons. Future research may reveal the ingredient of propolis and may specifically pinpoint its activity for each pathogen.

\subsection{Aksu Vital Shiffa $H_{0 m e} e^{R}(A H)$ and Balen ${ }^{R}$ (BN) propolis extract induced selected plant defense genes differently}

Plant defense systems take the role to protect plants against various biotic stresses. Salicylic acid (SA) is a phytohormone that regulates the plant immune system against many pathogens. Previous reports showed that exogenous application of SA may induce the defense system and protect the plant 


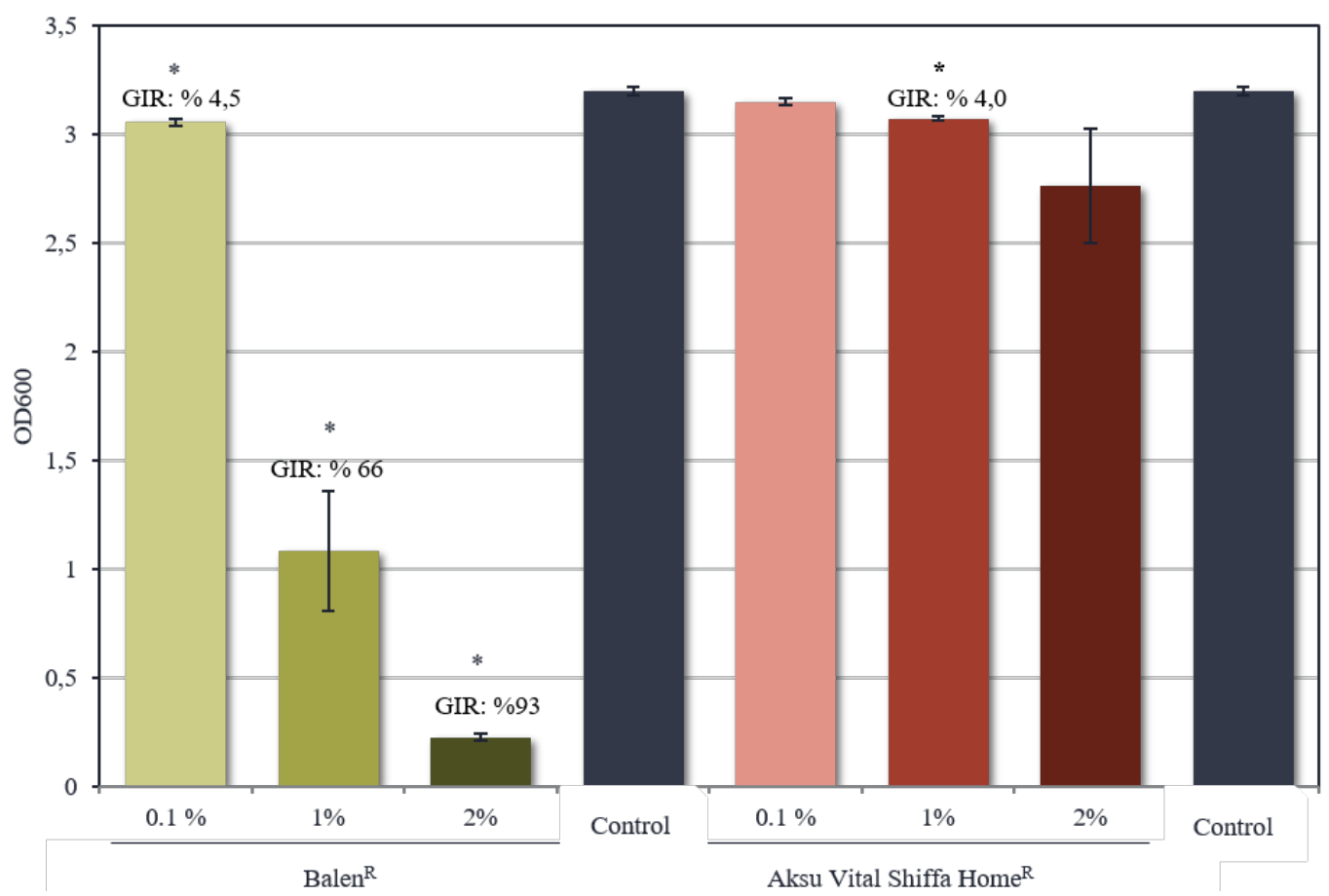

Figure 1. Antibacterial activity of Aksu Vital Shiffa $\mathrm{Home}^{\mathrm{R}}$ and Balen ${ }^{\mathrm{R}}$ propolis extracts against Pst $\mathrm{DC} 3000^{*}$

*: Bacterial growth inhibition rates (GIR) significantly different compared to the control group based on Student's t-tests $(\mathrm{p}<0.05)$ are marked by asterisks. Error bars represent the standard error of the mean based on at least three independent replicates.

against a variety of pathogens systemically (Reddy, 2013; Bektas and Eulgem, 2015). In recent years, researchers explored synthetic or natural compounds, plant defense activators, that induce plant defense systems. Some of these chemicals are characterized as functional analogs of SA, however, some of them have distinct functional mechanisms (Knoth et al., 2009; Noutoshi et al., 2012; Reddy, 2013; Bektas and Eulgem, 2015; Cohen et al., 2016). For example, Acibenzolar-S- methyl (ASM) and 2,6-Dichloro-isonicotinic acid (INA) are discovered as synthetic elicitors, however, DL- $\beta$ aminobutyric acid (BABA) and chitosan are natural products that were characterized as plant defense activators (Bektas and Eulgem, 2015, Cohen et al., 2016). Propolis is a promising natural product in terms of many areas including plant protection and its activity as a plant defense activator is still unknown. In this study, the activator potential of propolis was evaluated by monitoring plant defense gene induction activity using two commercially available propolis extracts. To understand the activity of two different propolis sources, Col-0 plants were grown for four weeks and $1 \% \mathrm{BN}, 2 \%$ $\mathrm{BN}, 1 \% \mathrm{AH}, 2 \% \mathrm{AH}$, or water (as control) were applied to plants 24 hours ahead of collecting plant tissues. To elicit defense gene expression, WRKY70 and $C a B P 22$ genes were used as a marker. These genes are two important defense genes that involve downstream of the SA pathway. Actin 18 gene is used as a housekeeping gene for these experiments
(Table 1). According to semi-quantitative RT-PCR results, two different propolis extracts induced defense genes differently. $1 \%$ of $\mathrm{BN}$ did not induce either WRKY70 or CaBP22 gene expressions significantly, but at $2 \% \mathrm{BN}$ concentration $\mathrm{CaBP} 22$ gene expression indicated a stronger band than the control group and actin 18 housekeeping gene. On the other side, $1 \%$ of $\mathrm{AH}$ induced WRKY70 gene expression significantly, but not the expression of CaBP22 (Figure 2). At 2\% AH concentration, both WRKY70 and CaBP22 gene expressions were induced compared to control groups. The results demonstrated that the transcription activity of these genes was induced by propolis, but these two propolis sources induce gene expressions differently. The genes that were induced and propolis concentrations that induce gene expression were different. These results were also consistent with the antibacterial activity assay. The antibacterial activity of these extracts was also different for each source and dose. Since transcription activity of these genes was induced by propolis, it may indicate that propolis may potentially induce plants' defense system. Therefore, the preliminary results of this study showed promising activity of propolis as a plant defense activator. Further studies on propolis with in-vivo experiments may reveal a deeper understanding of propolis in plant defense mechanisms. 


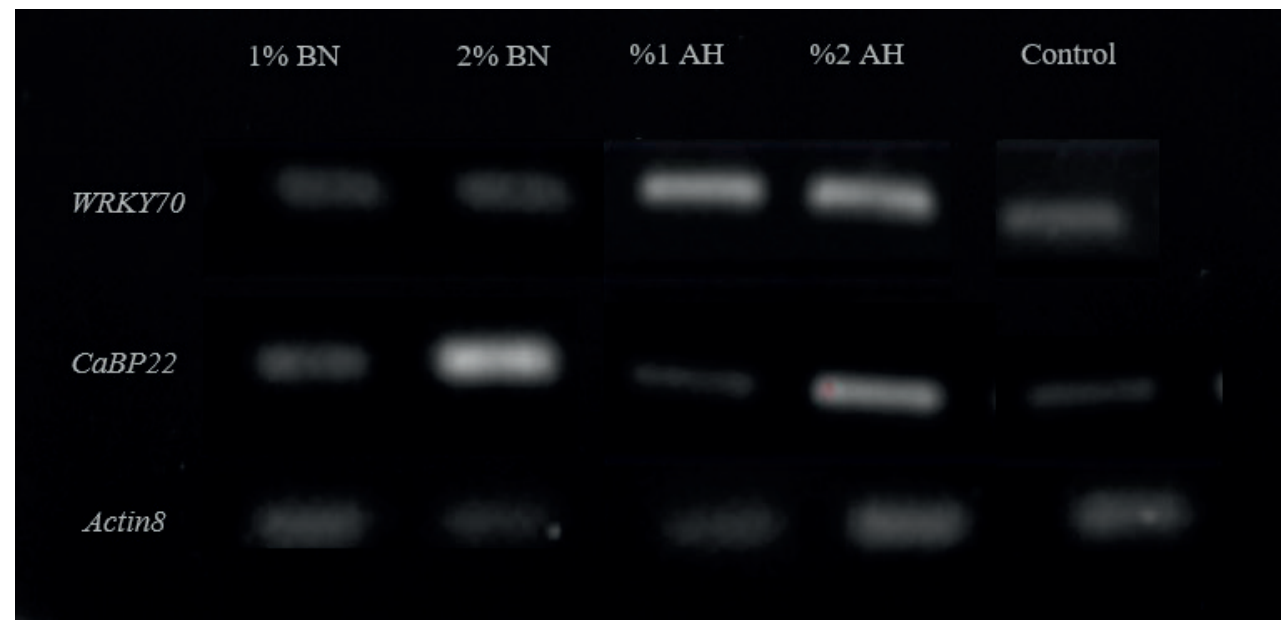

Figure 2. Analysis of plant defense gene induction activity of two commercially available propolis extracts

\subsection{Aksu Vital Shiffa $\mathrm{Home}^{\mathrm{R}}(\mathrm{AH})$ and Balen ${ }^{\mathrm{R}}$} (BN) propolis extracts do not have negative effects on plant growth

Antibacterial activity and possible defense inducer activity of propolis may come with side effects on plant growth. To elicit potential side effects of these two propolis sources, A. thaliana Col-0 plants were grown for four weeks with indicated concentrations of propolis extracts. According to results, for both propolis sources, the application of 1 and $2 \%$ propolis concentrations did not reduce plant growth (Figure 3). Plants grow similar to the control group that was irrigated regularly with $\mathrm{ddH}_{2} \mathrm{O}$. These results demonstrated that propolis has potential as a plant protectant and did not inhibit plant growth. Positive results encouraged the use of propolis as a natural alternative to chemical pesticides.

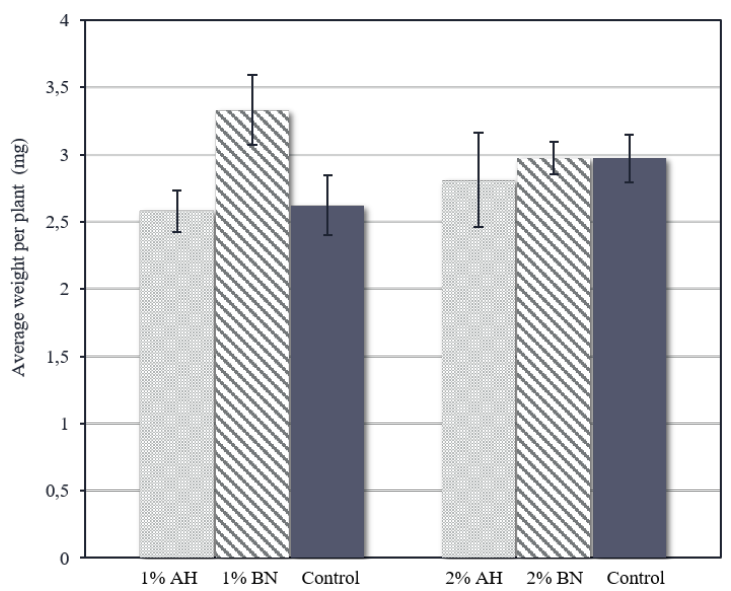

Figure 3. Effect of Aksu Vital Shiffa $\operatorname{Home}^{\mathrm{R}}(\mathrm{AH})$ and $\mathrm{Balen}^{\mathrm{R}}(\mathrm{BN})$ propolis extracts on plant growth ${ }^{*}$ *: The Student's t-test was used to determine if the propolis has any effects on Arabidopsis growth. The data represents at least three independent experiments.

\section{Conclusions}

Two commercially available liquid propolis extracts $\left(\right.$ Balen $^{\mathrm{R}}$ and Aksu Vital Shiffa Home ${ }^{\mathrm{R}}$ ) were evaluated and compared for antibacterial activity, effect on plant growth, and plant defense gene-inducing capability. The results indicated significant differences in the effect of each extract on plant defense and antibacterial activity. Even though both sources were effective to inhibit the growth of Pst DC3000, the extracts of BN (all doses) were significantly more effective compared to $\mathrm{AH}(1 \%)$. The expressions of WRKY70 and $C a B P 22$ in $\mathrm{BN}$ and $\mathrm{AH}$ were different when two products and control were compared. The results highlighted the potential of propolis in plant protection and other areas of agriculture. There is a need for further studies to evaluate and understand the interactions between propolis, plants, and pathogens.

\section{Acknowledgments}

This work was supported by TUBİTAK-2209National/International Research Projects Fellowship Programme for Undergraduate Students $2017 / 2$ with the application number 1919B011702852.

\section{References}

Abd-El-Rhman, A.M., 2009. Antagonism of Aeromonas hydrophila by propolis and its effect on the performance of Nile tilapia, Oreochromis niloticus. Fish and Shellfish Immunology, 27(3): 454-459.

Abo-Elyousr, K.A.M., Seleim, M.E.A., El-Sharkawy, R.M., Khalil Bagy, H.M.M., 2017. Effectiveness of Egyptian propolis on control of tomato bacterial wilt caused by Ralstonia solanacearum. Journal of Plant Diseases and Protection, 124(5): 467-472.

Ali, A.M., Kunugi, H., 2021. Propolis, bee honey, and their components protect against coronavirus disease 
2019 (COVID-19): A review of in silico, in vitro, and clinical studies. Molecules, 26(5): 1232.

Aparicio-García, P.F., Ventura-Aguilar, R.I., Del RíoGarcía, J.C., Hernández-López, M., Guillén-Sánchez, D., Salazar-Piña, D.A., Ramos-García, M.D.L., Bautista-Baños, S., 2021. Edible chitosan/propolis coatings and their effect on ripening, development of Aspergillus flavus, and sensory quality in fig fruit, during controlled storage. Plants, 10(1): 112.

Awale, S., Li, F., Onozuka, H., Esumi, H., Tezuka, Y., Kadota, S., 2008. Constituents of Brazilian red propolis and their preferential cytotoxic activity against human pancreatic PANC-1 cancer cell line in nutrient-deprived condition. Bioorganic \& Medicinal Chemistry, 16(1): 181-189.

Basim, E., Basim, H., Özcan, M., 2006. Antibacterial activities of Turkish pollen and propolis extracts against plant bacterial pathogens. Journal of Food Engineering, 77(4): 992-996.

Bektas, Y., Eulgem, T., 2015. Synthetic plant defense elicitors. Frontiers in Plant Science, 5(804): 1-17.

Bohinc, T., Vučajnk, F., Trdan, S., 2019. The efficacy of environmentally acceptable products for the control of major potato pests and diseases. ZemdirbysteAgriculture, 106(2): 135-142.

Botteon, C.E.A., Silva, L.B., Ccana-Ccapatinta, G.V., Silva, T.S., Ambrosio, S.R., Veneziani, R.C.S., Bastos, J.K., Marcato, P.D., 2021. Biosynthesis and characterization of gold nanoparticles using Brazilian red propolis and evaluation of its antimicrobial and anticancer activities. Scientific Reports, 11(1): 1-16.

Burdock, G.A., 1998. Review of the biological properties and toxicity of bee propolis (Propolis). Food and Chemical Toxicology, 36(4): 347-363.

Cai, Y., Cao, X., Aballay, A., Nishikawa, Y., Davies, J.E., 2014. Whole-animal chemical screen identifies colistin as a new immunomodulator that targets conserved pathways. mBio, 5(4): 1-11.

Cohen, Y., Vaknin, M., Mauch-Mani, B., 2016. BABAinduced resistance: milestones along a 55-year journey. Phytoparasitica, 44(4): 513-538.

Da Silva Barboza, A., Aitken-Saavedra, J.P., Ferreira, M.L., Fábio Aranha, A.M., Lund, R.G., 2021. Are propolis extracts potential pharmacological agents in human oral health? - A scoping review and technology prospecting. Journal of Ethnopharmacology, 271: 113846.

Er, Y., 2021. In vitro and in vivo antimicrobial activity of propolis extracts against various plant pathogens. Journal of Plant Diseases and Protection, 128: 693701.

Farace, G., Fernandez, O., Jacquens, L., Coutte, F., Krier, F., Jacques, P., Clément, C., Barka, E.A., Jacquard, C., Dorey, S., 2015. Cyclic lipopeptides from Bacillus subtilis activate distinct patterns of defence responses in grapevine. Molecular Plant Pathology, 16(2): 177187.

Freires, I.A., Queiroz, V., Furletti, V.F., Ikegaki, M., de Alencar, S.M., Duarte, M.C.T., Rosalen, P.L., 2016. Chemical composition and antifungal potential of
Brazilian propolis against Candida spp. Journal of Medical Mycology, 26(2): 122-132.

Gallez, L., Kiehr, M., Fernández, L., Delhey, R., Stikar, D., 2015. Antifungal activity in vitro of propolis solutions from Argentina against two plant pathogenic fungi: Didymella bryoniae and Rhizotocnia solani. Journal of Apicultural Research, 53(4): 438-440.

Halder, V., Suliman, M.N.S., Kaschani, F., Kaiser, M., 2019. Plant chemical genetics reveals colistin sulphate as a SA and NPR1-independent PR1 inducer functioning via a p38-like kinase pathway. Scientific Reports, 9(1): 11196.

Henry, G., Deleu, M., Jourdan, E., Thonart, P., Ongena, M., 2011. The bacterial lipopeptide surfactin targets the lipid fraction of the plant plasma membrane to trigger immune-related defence responses. Cellular Microbiology, 13(11): 1824-1837.

Huang, S., Zhang, C P., Wang, K., Li, G.Q., Hu, F.L., 2014. Recent advances in the chemical composition of propolis. Molecules, 19(12): 19610-19632.

Ishihara, M., Naoi, K., Hashita, M., Itoh, Y., Suzui, M., 2009. Growth inhibitory activity of ethanol extracts of Chinese and Brazilian propolis in four human colon carcinoma cell lines. Oncology reports, 22(2): 349-354.

Jug, M., Končić, M.Z., Kosalec, I., 2014. Modulation of antioxidant, chelating and antimicrobial activity of poplar chemo-type propolis by extraction procures. LWT-Food Science and Technology, 57(2): 530-537.

Knoth, C., Salus, M.S., Girke, T., Eulgem, T., 2009. The synthetic elicitor 3,5-dichloroanthranilic acid induces NPR1-dependent and NPR1-independent mechanisms of disease resistance in Arabidopsis. Plant Physiology, 150(1): 333-347.

Kolayli, S., Palabiyik, I., Atik, D.S., Keskin, M., Bozdeveci, A., Karaoglu, S.A., 2020. Comparison of antibacterial and antifungal effects of different varieties of honey and propolis samples. Acta Alimentaria, 49(4): 515-523.

Lima Cavendish, R., de Souza Santos, J., Belo Neto, R., Oliveira Paixao, A., Valeria Oliveira, J., Divino de Araujo, E., Berretta, E., Silva, A.A., Maria Thomazzi, S., Cordeiro Cardoso, J., Zanardo Gomes, M., 2015. Antinociceptive and anti-inflammatory effects of Brazilian red propolis extract and formononetin in rodents. Journal of Ethnopharmacology, 173: 127133.

Martinello, M., Mutinelli, F., 2021. Antioxidant activity in bee products: A review. Antioxidants, 10(1): 71.

Noutoshi, Y., Okazaki, M., Kida, T., Nishina, Y., Morishita, Y., Ogawa, T., Suzuki, H., Shibata, D., Jikumaru, Y., Hanada, A., Kamiya, Y., Shirasu, K., 2012. Novel plant immune-priming compounds identified via high-throughput chemical screening target salicylic acid glucosyltransferases in Arabidopsis. Plant Cell, 24(9): 3795-3804.

Ordonez, R.M., Zampini, I.C., Moreno, M.I., Isla, M.I., 2011. Potential application of Northern Argentine propolis to control some phytopathogenic bacteria. Microbiological Research, 166(7): 578-584. 
Pascoal, A., Feás, X., Dias, T., Dias, L.G., Estevinho, L.M., 2014. The role of honey and propolis in the treatment of infected wounds. In: K. Kon, M. Rai (Eds.), Microbiology for Surgical Infections, Academic Press, Amsterdam, pp. 221-234.

Reddy, P.P., 2013. Plant Defence Activators. Springer, New Delhi.

Regueira, M.S.N., Tintino, S.R., Da Silva, A.R.P., Costa, M.D.S., Boligon, A.A., Matias, E.F.F., De Queiroz Balbino, V., Menezes, I.R.A., Melo Coutinho, H.D., 2017. Seasonal variation of Brazilian red propolis: Antibacterial activity, synergistic effect and phytochemical screening. Food and Chemical Toxicology, 107(Pt B): 572-580.

Rivera-Yañez, N., Rivera-Yañez, C.R., Pozo-Molina, G., Méndez-Catalá, C.F., Méndez-Cruz, A.R., NietoYañez, O., 2020. Biomedical properties of propolis on diverse chronic diseases and its potential applications and health benefits. Nutrients, 13(1): 78 .

Salatino, A., Teixeira, E.W., Negri, G., Message, D., 2005. Origin and chemical variation of Brazilian propolis. Evidence-Based Complementary and Alternative Medicine, 2(1): 33-38.

Scorza, C.A., Gonçalves, V.C., Scorza, F.A., Fiorini, A.C., De Almeida, A.C.G., Fonseca, M.C.M., Finsterer, J., 2020. Propolis and coronavirus disease 2019 (COVID-19): Lessons from nature. Complementary Therapies in Clinical Practice, 41: 101227.

Sforcin, J.M., Bankova, V., 2011. Propolis: is there a potential for the development of new drugs? Journal of Ethnopharmacology, 133(2): 253-260.

Silva-Castro, I., Diez, J., Martín-Ramos, P., Pinto, G., Alves, A., Martín-Gil, J., Martín-García, J., 2018.
Application of bioactive coatings based on chitosan and propolis for Pinus spp. protection against Fusarium circinatum. Forests, 9(11): 685.

Valente, M.J., Baltazar, A.F., Henrique, R., Estevinho, L., Carvalho, M., 2011. Biological activities of Portuguese propolis: protection against free radicalinduced erythrocyte damage and inhibition of human renal cancer cell growth in vitro. Food and Chemical Toxicology, 49(1): 86-92.

Wagh, V.D., 2013. Propolis: a wonder bees product and its pharmacological potentials. Advances in Pharmacological and Pharmaceutical Sciences, 2013: 308249.

Xin, X.F., He, S.Y., 2013. Pseudomonas syringae pv. tomato DC3000: a model pathogen for probing disease susceptibility and hormone signaling in plants. Annual Review of Phytopathology, 51: 473498.

Xu, J., Zhang, Y., 2020. Traditional Chinese Medicine treatment of COVID-19. Complementary Therapies in Clinical Practice, 39: 101165.

Yong, H., Liu, J., 2021. Active packaging films and edible coatings based on polyphenol-rich propolis extract: A review. Comprehensive Reviews in Food Science and Food Safety, 20(2): 2106-2145.

Zabaiou, N., Fouache, A., Trousson, A., Baron, S., Zellagui, A., Lahouel, M., Lobaccaro, J.A. 2017. Biological properties of propolis extracts: Something new from an ancient product. Chemistry and Physics of Lipids, 207(Pt B): 214-222.

Zampini, I.C., Salas, A.L., Maldonado, L.M., Simirgiotis, M.J., Isla, M.I., 2021. Propolis from the Monte region in Argentina: a potential phytotherapic and food functional ingredient. Metabolites, 11(2): 76. 